\title{
Correlation versus Interchangeability: The Limited Robustness of Empirical Findings on Democracy using Highly Correlated Datasets
}

\author{
Gretchen Casper \\ Penn State University \\ Claudiu Tufis \\ Penn State University
}

\begin{abstract}
This article shows that highly correlated measures can produce different results. We identify a democratization model from the literature and test it in over 120 countries from 1951-1992. Then, we check whether the results are robust regarding measures of democracy, time periods, and levels of development. The findings show that measures do matter: while some of the findings are robust, most of them are not. This explains, in part, why the debates on democracy have continued rather than been resolved. More importantly, it underscores the need for more careful use of measures and further testing to increase confidence in the findings. Scholars in comparative politics increasingly are drawn to large- $\mathrm{N}$ statistical analyses, often using datasets collected by others. As in any field, we show how they must be careful in choosing the most appropriate measures for their study, without assuming that any correlated measure will do.
\end{abstract}

\section{Introduction}

Democracy, like representation or power, is a basic concept in political science that is inherently difficult to measure. While different scholars have accepted different tradeoffs between consistency and operationalization when constructing their measures, resulting in a range of different measures of democracy, their measures correlate highly. It would be a reasonable assumption for a researcher to treat the measures interchangeably, selecting one that best fits the time period, number of countries, or particular variables that she was interested in. However, as we show in this article, despite high correlations, the use of these different measures can produce different results

Authors' note: We acknowledge generous advice from Frank Baumgartner, Scott Bennett, David Brown, Suzanna DeBoef, Scott Gates, Barbara Geddes, and Quan Li. 
This article proceeds as follows. First, we describe three measures of democracy that are commonly used to study democratization, noting their high levels of correlation. Secondly, we identify a model of democratization from the literature and test it in over 120 countries from 1951-1992. Third, we check the robustness of the findings across measures of democracy, time periods, and levels of development. The conclusion points out that different measures lead to different results: coefficients change directions, size, and statistical significance. This has strong implications for democratization scholars, but probably is a common problem for researchers in other areas as well. Scholars should beware: correlation does not imply interchangeability.

\section{Measuring Democracy}

Dahl argues that democracy entails competition and participation: candidates for public office compete in elections and citizens participate in the process by selecting the winners $(1971,4){ }^{1}$ Scholars have revised this minimal definition by including additional dimensions such as political rights and civil liberties (Diamond 1999); socioeconomic equality (Huber, Rueschemeyer, and Stephens 1997); uncertainty (Przeworski 1991); and the absence of military influence (Schmitter and Karl 1991, 81). Not surprisingly, the number of measures of democracy mirrors this diversity of definitions. ${ }^{2}$ These measures include Polity (Marshall and Jaggers 2000), Polyarchy (Vanhanen 2000b), Freedom House (2001), Political Regime Change (Gasiorowski 1996), Democracy and Development (Przeworski et. al. 2000), as well as measures constructed by Arat (1988), Bollen (1980, 1993), Coppedge and Reinecke (1991), and Mainwaring et al. (2001). It is common for the authors to show that their measures correlate with the others, to establish the reliability of their measures. However, while these measures may correlate highly, they vary in a number of ways, including the dimensions used to measure democracy, the time period covered, and the number of countries included.

This article compares three measures of democracy: Polity IV, Polyarchy 1.2, and Freedom House. First, they are three of the most widely used measures in democratization research (Munck and Verkuilen forthcoming). Second, they are the most similar in that all three consciously start from Dahl's definition of democracy. Finally, these three measures are highly correlated with each other (ranging between .85 and .92). By choosing these highly correlated measures all drawing from a similar conceptual measure, we set up a most difficult case for our analysis. If we find that the results from testing a model of democratization are not robust using these three measures, then the problem would be even worse if other, more diverse, measures were incorporated into our research. Below, we discuss how these three measures operationalized democracy.

\footnotetext{
${ }^{1}$ For a review of definitions of democracy used in the democratization literature, see Collier and Levitsky (1997).

${ }^{2}$ For a review of measures of democracy, see Munck and Verkuilen (forthcoming).
} 
Polity was originally constructed to test the durability of states (Jaggers and Gurr 1995, 470). It includes democracy and autocracy indicators for over 160 countries from 1800-1999 by coding five institutional dimensions (Jaggers and Gurr 1995, 471-2). Both of the democracy and autocracy indicators were constructed as 11-point scales. Vanhanen (2000a, 253) constructed Polyarchy to explain "the emergence of democracy." Polyarchy codes 187 countries from 1810 to 1998 on competition and participation and then equally weights them to create a democracy index. Although the Freedom House survey was created to measure freedom, it is "essentially a survey on democracy" (Gastil 1991, 22). The annual surveys coded 192 countries from 1973 to the present across two dimensions -- political rights and civil liberties -- on a 7-point scale, whereby countries coded 1 were most free and those coded 7 were least free (Gastil 1991, 24). ${ }^{3}$

Democracy is a difficult concept to measure; yet the high correlations suggest that these three measures generally code countries in very similar ways. It is not surprising, then, that scholars would treat the three measures as virtually interchangeable, choosing to use whichever one had more complete coverage of the time period they were interested in, more favorable geographic coverage, or some other reason. This practice, though seemingly reasonable, is more hazardous than scholars realize. The next section tests a model of democratization to assess the robustness of the findings using these three highly correlated measures of democracy.

\section{Model of Democratization}

Scholars have constructed a wide range of models to explain why some countries are democratic and others are not. The results from these tests have enhanced rather than ended debates in democratization, as findings have been inconsistent. ${ }^{4}$ Democratization theorists see these as conceptual debates. However, it may be that there is a methodological explanation for why these debates have continued. As we shall see, use of these highly correlated measures leads to different results. Below, we introduce the model of democratization used in this study.

We used the three measures of democracy discussed earlier. As is commonly done with Polity data (Gleditsch and Ward 1997, 376), we subtracted a country's autocracy score from its democracy score and added ten points to create an annual measure that ranged between 0 (not democratic) and 20 (most democratic). For Polyarchy, we used Vanhanen's democracy index. With Freedom House, we followed standard practice: we transposed the two Freedom House scales (for political rights and civil liberties) and added them together to create a 13-point scale from 2 (least free) to 14 (most free).

To explain levels of democracy, we included socioeconomic and institutional explanatory variables commonly used in democratization studies. The six socioeconomic variables are income, growth, trade dependence, inflation, primary

\footnotetext{
${ }^{3}$ For an extended discussion of these three measures, see Gleditsch and Ward 1997, Gates et. al. 2001, Mainwaring et. al. 2001, and Munck and Verkuilen (forthcoming).

${ }^{4}$ See, for example, Lipset (1959), Przeworski et. al. (2000), Linz (1994), Mainwaring and Shugart (1997), and Geddes (1998).
} 
education, and secondary education. Income is measured as logged real GDP per capita. Growth is the growth rate of real per capita income. Trade dependence is measured as openness, which is the sum of exports and imports divided by real GDP per capita. Inflation is measured by the Consumer Price Index. ${ }^{5}$ Primary education and secondary education are measured as the percentage of the population enrolled in primary or secondary school. ${ }^{6}$ The two institutional variables are types of executive systems and party fractionalization. A country's executive system was coded annually as one of three possible types: presidential, parliamentary, and other. ${ }^{7}$ To measure party fractionalization, we adopted Rae's index, which calculates the probability that any two legislators selected at random are members of the same political party (Rae 1968). ${ }^{8}$ The next section presents the results from the democratization model and robustness checks.

\section{Results}

We tested the democratization model in over 120 countries, from 1951-1992. ${ }^{9}$ Because the dataset pools across countries and years, OLS results may report incorrect standard errors due to potential problems with heteroskedasticity, contemporaneous correlation, and serial correlation. Because of these issues, we applied regression analysis with panel-corrected standard errors (PCSEs) (Beck and Katz 1995, 636). We then checked the robustness of the findings, paying particular attention to the measures for democracy, time periods, and levels of development.

First, we tested the democratization model from 1951 to 1992 using two measures of democracy: Polity and Polyarchy. ${ }^{10}$ We lagged the explanatory variables and tested the model using the same country-years from both Polity and Polyarchy. The results are shown in the first two columns of Table 1. Four of the explanatory variables are significant regardless of the measure of democracy employed -- income, parliamentary systems, and party fractionalization are positively related to democracy, while growth is negatively associated with democracy.

\footnotetext{
${ }^{5}$ Data for these variables are taken from the Penn World Tables 5.6 (Heston et. al. 1995), International Financial Statistics (International Monetary Fund 1992), and World Development Indicators (World Bank 1997).

${ }^{6}$ These data were taken from Banks (1999) and the World Development Indicators (World Bank 1997).

${ }^{7}$ The type of executive system was coded from annual volumes of the Political Handbook of the World (1950-1962, 1975-1996), Political Handbook and Atlas of the World (1963-1970), and the related supplements to these volumes (1970-1973). To code a country as having one of the first two types, definitions by Shugart and Carey (1992), Linz (1994), Sartori (1997), and Mainwaring and Shugart (1997) were consulted. The executive type "other" included mixed systems, monarchies, juntas, revolutionary councils, multi-person executives, and transitional governments. Type of executive was coded according to a country's constitution, as described in Banks' annual volumes. As a result, countries that had authoritarian or communist regimes could be coded as presidential or parliamentary systems depending on their constitutional arrangements. This coding rule was implemented so that the type of executive would not measure level of democracy or type of regime.

${ }^{8}$ The party fractionalization data are taken from Banks (1999).

${ }^{9}$ Countries were included in this study, starting in 1950, if their population was greater than one million people by 1990, as reported in Banks (1990) or the United Nations (1994). Countries that did not meet this threshold, that were not independent states, or that did not have sufficient socioeconomic data to conduct the analysis were excluded.

${ }^{10}$ We did not include Freedom House in the initial test because it starts in 1973.
} 
Table 1 Democratization Model: Measures of Democracy and Time

\begin{tabular}{|c|c|c|c|c|c|c|c|}
\hline & \multicolumn{2}{|c|}{$1951-1992$} & \multicolumn{2}{|c|}{$1951-1973$} & \multicolumn{3}{|c|}{$1975-1992$} \\
\hline & Polity & Polyarchy & Polity & Polyarchy & Polity & Polyarchy & $\begin{array}{c}\text { Freedom } \\
\text { House }\end{array}$ \\
\hline GDP pc, logged & $\begin{array}{l}3.614 * * * \\
(.207)\end{array}$ & $\begin{array}{l}6.580 * * * \\
(.349)\end{array}$ & $\begin{array}{l}2.806 * * * \\
(.356)\end{array}$ & $\begin{array}{l}5.782 * * * \\
(.619)\end{array}$ & $\begin{array}{l}3.372 * * * \\
(.280)\end{array}$ & $\begin{array}{l}6.549 * * * \\
(.492)\end{array}$ & $\begin{array}{l}2.236 * * * \\
(.132)\end{array}$ \\
\hline Real GDP pc growth & $\begin{array}{l}-0.018 * * \\
(.006)\end{array}$ & $\begin{array}{l}-0.038 * * * \\
(.009)\end{array}$ & $\begin{array}{r}-0.013 \\
(.011)\end{array}$ & $\begin{array}{r}-0.023 \\
(.013)\end{array}$ & $\begin{array}{l}-0.023 * * \\
(.009)\end{array}$ & $\begin{array}{l}-0.046 * * * \\
(.014)\end{array}$ & $\begin{array}{l}-0.010 * \\
(.004)\end{array}$ \\
\hline Openness & $\begin{array}{l}-0.009 * \\
(.004)\end{array}$ & $\begin{array}{r}-0.012 \\
(.007)\end{array}$ & $\begin{array}{r}-0.016 \\
(.009)\end{array}$ & $\begin{array}{r}-0.021 \\
(.016)\end{array}$ & $\begin{array}{l}-0.009 * \\
(.004)\end{array}$ & $\begin{array}{r}-0.012 \\
(.008)\end{array}$ & $\begin{array}{r}-0.004 \\
(.002)\end{array}$ \\
\hline Inflation & $\begin{array}{r}-0.009 \\
(.008)\end{array}$ & $\begin{array}{l}0.009 \\
(.009)\end{array}$ & $\begin{array}{l}0.030 \\
(.030)\end{array}$ & $\begin{array}{l}0.089 \\
(.050)\end{array}$ & $\begin{array}{r}-0.002 \\
(.010)\end{array}$ & $\begin{array}{l}0.016 \\
(.013)\end{array}$ & $\begin{array}{r}-0.003 \\
(.003)\end{array}$ \\
\hline Primary education & $\begin{array}{r}-0.043 \\
(.035)\end{array}$ & $\begin{array}{l}-0.212 * * * \\
(.056)\end{array}$ & $\begin{array}{l}0.069 \\
(.061)\end{array}$ & $\begin{array}{r}-0.142 \\
(.076)\end{array}$ & $\begin{array}{l}-0.102 * \\
(.047)\end{array}$ & $\begin{array}{l}-0.236 * * \\
(.088)\end{array}$ & $\begin{array}{l}-0.038 * \\
(.018)\end{array}$ \\
\hline Secondary education & $\begin{array}{l}0.036 \\
(.071)\end{array}$ & $\begin{array}{l}0.121 \\
(.124)\end{array}$ & $\begin{array}{l}0.368 * * * \\
(.102)\end{array}$ & $\begin{array}{l}0.213 \\
(.183)\end{array}$ & $\begin{array}{l}0.055 \\
(.099)\end{array}$ & $\begin{array}{l}0.159 \\
(.171)\end{array}$ & $\begin{array}{l}0.030 \\
(.042)\end{array}$ \\
\hline Presidential & $\begin{array}{l}0.245 \\
(.248)\end{array}$ & $\begin{array}{r}-0.080 \\
(.382)\end{array}$ & $\begin{array}{l}0.238 \\
(.377)\end{array}$ & $\begin{array}{r}-0.061 \\
(.569)\end{array}$ & $\begin{array}{l}0.508 \\
(.416)\end{array}$ & $\begin{array}{l}0.011 \\
(.621)\end{array}$ & $\begin{array}{l}0.607 * * * \\
(.191)\end{array}$ \\
\hline Parliamentary & $\begin{array}{l}2.061 * * * \\
(.410)\end{array}$ & $\begin{array}{l}3.446 * * * \\
(.548)\end{array}$ & $\begin{array}{l}3.390 * * * \\
(.561)\end{array}$ & $\begin{array}{l}5.043 * * * \\
(.648)\end{array}$ & $\begin{array}{l}2.059 * * * \\
(.592)\end{array}$ & $\begin{array}{l}2.924 * * * \\
(.880)\end{array}$ & $\begin{array}{l}0.768 * * * \\
(.230)\end{array}$ \\
\hline Party Fractionalization & $\begin{array}{l}2.788 * * * \\
(.514)\end{array}$ & $\begin{array}{l}7.294 * * * \\
(.741)\end{array}$ & $\begin{array}{l}3.931 * * * \\
(.894)\end{array}$ & $\begin{array}{l}8.050 * * * \\
(1.176)\end{array}$ & $\begin{array}{l}3.598 * * * \\
(.869)\end{array}$ & $\begin{array}{l}7.424 * * * \\
(1.254)\end{array}$ & $\begin{array}{l}1.864 * * * \\
(.465)\end{array}$ \\
\hline Constant & $\begin{array}{l}-17.812 * * * \\
(1.463)\end{array}$ & $\begin{array}{l}-40.396 * * * \\
(2.280)\end{array}$ & $\begin{array}{l}-14.589 * * * \\
(2.670)\end{array}$ & $\begin{array}{l}-36.292 * * * \\
(4.214)\end{array}$ & $\begin{array}{l}-16.291 * * * \\
(1.704)\end{array}$ & $\begin{array}{l}-40.612 * * * \\
(2.899)\end{array}$ & $\begin{array}{l}-9.713 * * * \\
(.882)\end{array}$ \\
\hline$\overline{\mathrm{N}}$ & 2812 & 2812 & 1245 & 1245 & 1402 & 1402 & 1402 \\
\hline $\mathrm{R}^{2}$ & .35 & .38 & .44 & .41 & .39 & .42 & .58 \\
\hline Wald Test & 864.48 & 1814.86 & 425.13 & 832.87 & 822.01 & 1197.54 & 1345.52 \\
\hline Probability $>\chi^{2}$ & 0.000 & 0.000 & 0.000 & 0.000 & 0.000 & 0.000 & 0.000 \\
\hline
\end{tabular}


Looking at the other variables, we can see that while primary education is significantly associated with democracy when using Polyarchy, its significance drops out when using Polity. Trade openness, in turn, is significant only when using Polity as a measure of democracy. The unstable results of these two explanatory variables may be influenced by Polity's operationalization of democracy, which focuses on institutional aspects. Inflation and presidential systems, while not significant, switch the directions of their associations depending on whether we use Polity or Polyarchy. The results from the democratization model show that using the same model, the same country-years, but different measures of democracy generates different results.

Next, we checked the robustness of the findings for the democratization model across time and level of development. The first test considers whether the relationships between certain variables and levels of democracy change across time, and if so, whether these changes are consistent for all three measures of democracy. The extension of the right to vote over time has generated higher levels of political participation, while the effect of inflation has changed over time (Gasiorowski 1995). To test the model across different time periods, we divided the data into two sets: 19511973 and 1975-1992. We chose 1974 as the dividing point for theoretical and practical purposes. Since the Third Wave of democratization began in 1974 (Huntington 1991), resulting in a sizeable increase in the number of democracies in the world, we can group the Third Wave period as a distinct set. In addition, this division results in two datasets of relatively equal size. For the first time period, 1951-1973, we used the same country-years from Polity and Polyarchy. For the second time period, 1975-1992, we included Freedom House and used the same country-years from all three measures.

As we can see from Table 1, three of the nine explanatory variables have stable results across all three measures and both time periods: income, parliamentary systems, and party fractionalization are positively and significantly associated with democracy. The remaining variables have inconsistent results. Also, the choice of measures of democracy has an important influence on the size of variance explained. For example, for 1975-1992, the model best explains levels of democracy when it uses Freedom House (58\% of total variance), followed by Polyarchy (42\%), and Polity (39\%). The comparison suggests that the results one obtains are a function of the measures used for democracy.

Growth is negatively associated with democracy during 1975-1992 for all three measures, but with different levels of significance. Openness is significantly and negatively related to democracy during 1975-1992 only when using Polity. Primary education is not significant prior to 1974 but is significantly and negatively related to democracy for 1975-1992 with all three measures. Secondary education, on the other hand, has a significant positive association for 1951-1973, but only when using Polity. Presidential systems show a significant positive association in 1975-1992 but only with Freedom House.

One could explain the different coefficients in the two subsamples by arguing that the effects of some variables might change over time. Such an interpretation, however, holds only if the variables are consistent inside each subsample, regardless of the measure of democracy used. As we have seen above, this is not the case for openness, 
secondary education, and presidential systems. Thus, the findings in these two subsamples add more evidence supporting our conclusion that the choice of measures affects the results of the analysis.

Finally, regarding level of development, some scholars argue that the effect of the variables will be different in developed versus developing countries. To address this issue, they limit their cases to developing countries (Helliwell 1994, Gasiorowski and Power 1998). To see whether the effects are different for countries with different levels of development, we divided the sample into two - OECD countries and non-OECD countries - and reran the model separately for each subset. Again, we used the same country-years for all three measures.

As Table 2 shows, party fractionalization is positively and significantly associated with democracy for both OECD and non-OECD members. However, results for the other eight explanatory variables are unstable. The model explains a greater amount of variance for OECD countries compared to non-OECD members (although there are differences in the sizes of the coefficients and the levels of significance), suggesting that we know more about democracy in developed than in developing countries. Again, the choice of measures of democracy significantly affects the size of variance explained: in the OECD subsample the explained variance ranges between $88 \%$ (using Freedom House) and 52\% (using Polyarchy); in the non-OECD subsample the explained variance ranges between $40 \%$ (when using Freedom House) and 22\% (Polyarchy).

Income is significant in both subsamples for all three measures, with the exception of OECD countries when using Polyarchy. Growth is significantly but negatively associated with democracy for non-OECD countries when using Polity or Polyarchy. Openness has a positive significant association only for OECD countries and only when democracy is measured by Polyarchy or Freedom House. ${ }^{11}$ Inflation has a significant negative relationship for non-OECD countries, when using Freedom House, but no effect otherwise. Both primary and secondary education have a positive significant relationship for OECD members when using Polity or Freedom House, yet a significant negative effect for OECD members with Polyarchy. Presidential systems are positively and significantly associated with democracy for both OECD and non-OECD countries but only when using Freedom House. Parliamentary systems have a positive significant association for non-OECD countries only with Polity and Polyarchy.

The results in Table 2 strengthen our conclusion. Within each subsample, eight of the nine explanatory variables either have unstable significance or change the sign of their association (in the case of the education variables) depending on the measure of democracy one uses. Since the results are unstable within groups of countries with similar levels of development, the importance of the measure of democracy becomes evident.

\footnotetext{
${ }^{11}$ This result could be determined by the variable used to divide the sample, given that OECD is an organization that promotes "economic cooperation." Thus, their members may depend on international trade more than non-OECD members.
} 
Table 2 Democratization Model: Measures of Democracy and Level of Development

\begin{tabular}{|c|c|c|c|c|c|c|}
\hline & \multicolumn{3}{|c|}{ OECD (1951-1992) } & \multicolumn{3}{|c|}{ Non OECD (1951-1992) } \\
\hline & Polity & Polyarchy & $\begin{array}{c}\text { Freedom } \\
\text { House }\end{array}$ & Polity & Polyarchy & $\begin{array}{l}\text { Freedom } \\
\text { House }\end{array}$ \\
\hline GDP pc, logged & $\begin{array}{l}3.340 * \\
(1.579)\end{array}$ & $\begin{array}{r}4.952 \\
(2.634)\end{array}$ & $\begin{array}{l}2.534 * * * \\
(.481)\end{array}$ & $\begin{array}{l}2.055 * * * \\
(.294)\end{array}$ & $\begin{array}{l}2.891 * * * \\
(.548)\end{array}$ & $\begin{array}{l}1.414 * * * \\
(.137)\end{array}$ \\
\hline Real GDP pc growth & $\begin{array}{l}-0.044 \\
(.026)\end{array}$ & $\begin{array}{r}-0.091 \\
(.048)\end{array}$ & $\begin{array}{r}-0.019 \\
(.010)\end{array}$ & $\begin{array}{l}-0.015 * \\
(.007)\end{array}$ & $\begin{array}{l}-0.034 * * \\
(.011)\end{array}$ & $\begin{array}{r}-0.007 \\
(.004)\end{array}$ \\
\hline Openness & $\begin{array}{l}0.015 \\
(.009)\end{array}$ & $\begin{array}{l}0.043 * \\
(.018)\end{array}$ & $\begin{array}{l}0.009 * * \\
(.003)\end{array}$ & $\begin{array}{l}-0.003 \\
(.004)\end{array}$ & $\begin{array}{l}0.002 \\
(.006)\end{array}$ & $\begin{array}{l}0.000 \\
(.002)\end{array}$ \\
\hline Inflation & $\begin{array}{l}0.003 \\
(.010)\end{array}$ & $\begin{array}{l}0.019 \\
(.024)\end{array}$ & $\begin{array}{l}0.003 \\
(.004)\end{array}$ & $\begin{array}{l}-0.006 \\
(.011)\end{array}$ & $\begin{array}{r}-0.004 \\
(.011)\end{array}$ & $\begin{array}{l}-0.010 * \\
(.004)\end{array}$ \\
\hline Primary education & $\begin{array}{l}0.161 * * * \\
(.048)\end{array}$ & $\begin{array}{l}-0.272 * \\
(.126)\end{array}$ & $\begin{array}{l}0.108 * * * \\
(.021)\end{array}$ & $\begin{array}{l}0.014 \\
(.046)\end{array}$ & $\begin{array}{r}-0.050 \\
(.071)\end{array}$ & $\begin{array}{l}0.025 \\
(.020)\end{array}$ \\
\hline Secondary education & $\begin{array}{l}0.234 * * * \\
(.068)\end{array}$ & $\begin{array}{l}-0.691 * * * \\
(.188)\end{array}$ & $\begin{array}{l}0.111 * * * \\
(.034)\end{array}$ & $\begin{array}{l}0.045 \\
(.106)\end{array}$ & $\begin{array}{l}0.241 \\
(.158)\end{array}$ & $\begin{array}{l}0.025 \\
(.046)\end{array}$ \\
\hline Presidential & $\begin{array}{l}1.717 \\
(.942)\end{array}$ & $\begin{array}{r}-1.107 \\
(1.874)\end{array}$ & $\begin{array}{l}1.027 * * \\
(.339)\end{array}$ & $\begin{array}{l}0.546 \\
(.380)\end{array}$ & $\begin{array}{l}0.724 \\
(.488)\end{array}$ & $\begin{array}{l}0.617 * * * \\
(.184)\end{array}$ \\
\hline Parliamentary & $\begin{array}{l}0.898 \\
(.943)\end{array}$ & $\begin{array}{r}2.863 \\
(1.608)\end{array}$ & $\begin{array}{l}0.522 \\
(.296)\end{array}$ & $\begin{array}{l}2.120 * * \\
(.680)\end{array}$ & $\begin{array}{l}1.729 * \\
(.799)\end{array}$ & $\begin{array}{l}0.446 \\
(.292)\end{array}$ \\
\hline Party Fractionalization & $\begin{array}{c}5.756 * \\
(2.297)\end{array}$ & $\begin{array}{l}16.976 * * * \\
(3.253)\end{array}$ & $\begin{array}{l}2.932 * * * \\
(.693)\end{array}$ & $\begin{array}{l}3.567 * * * \\
(.821)\end{array}$ & $\begin{array}{l}7.465 * * * \\
(1.090)\end{array}$ & $\begin{array}{l}1.626 * * * \\
(.420)\end{array}$ \\
\hline Constant & $\begin{array}{r}-20.233 \\
(14.382)\end{array}$ & $\begin{array}{l}-24.553 \\
(24.272)\end{array}$ & $\begin{array}{l}-14.934 * * * \\
(4.362)\end{array}$ & $\begin{array}{l}-9.031 * * * \\
(1.837)\end{array}$ & $\begin{array}{l}-18.150 * * * \\
(3.080)\end{array}$ & $\begin{array}{l}-4.691 * * * \\
(.890)\end{array}$ \\
\hline$\overline{\mathrm{N}}$ & 431 & 431 & 431 & 1296 & 1296 & 1296 \\
\hline $\mathrm{R}^{2}$ & .70 & .52 & .88 & .24 & .22 & .40 \\
\hline Wald Test & 40.80 & 143.40 & 100.87 & 137.23 & 188.76 & 233.70 \\
\hline Probability $>\chi^{2}$ & 0.000 & 0.000 & 0.000 & 0.000 & 0.000 & 0.000 \\
\hline
\end{tabular}


To summarize this section, the results for only one variable - party fractionalization - are consistent across the three measures of democracy and two robustness checks. The results for other variables are inconsistent: coefficients became larger or smaller, significance levels increased or disappeared, and signs changed direction. The same explanatory variable is either significant or not and has a positive or a negative effect, depending only on the measure used in the analysis. We argue that the confusion in the democratization literature is explained largely by the instability of the results.

\section{Conclusion}

Over the last forty years, political scientists have studied why some countries are democratic while others are not, and why some countries are more democratic than others. To conduct this research, they have used different measures of democracy. The scholars who constructed these measures and the researchers who used them have consistently pointed out that they are highly correlated with each other. The implication is that they are interchangeable, leaving researchers free from worrying about alternative conceptions or sensitivity checks. Thus, researchers have based their choice of a particular measure on the time period covered, their preferred statistical applications, or the number of valid cases for the variables with which they are most concerned. Furthermore, scholars tend to assume that because the measures are highly correlated with each other, their findings do not depend on the particular measure used but rather are be robust across many or all of them. In this article, we show that this assumption is often erroneous.

We tested a model based on the democratization literature, using three different measures of democracy, and then checked for robustness. Of the nine variables tested here, three are consistent across the democracy measures and time periods (income, parliamentary system, and party fractionalization), but only one is consistent across the measures and all robustness checks (party fractionalization). The results explain in part why the debates in the field have continued rather than been resolved.

It is not uncommon for researchers to engage in venue-shopping. This is true not only for studies of democratization but also for other topics of study in political science. Given the inconsistent results, though, from using different measures that are highly correlated, scholars need to select measures carefully and explain their selection based on theoretical reasons rather than expediency or taste. Furthermore, they should also explain why they did not choose other measures that are considered standards in their field. Finally, researchers should explain why their results might vary depending on the measure employed. Given the availability of data and the relative ease of adding them to a dataset, one solution is for researchers to test their models using different measures and to keep the model that satisfies some requirement for robustness. Their analyses and their articles will be longer, but they will be taking statistical testing seriously in democratization, as well as in other fields of political science. 


\section{References}

Arat, Zehra. 1988. Democracy and Economic Development: Modernization Theory Revisited. Comparative Politics 21:21-36.

Banks, Arthur S., ed. 1975-1996. Political Handbook of the World. Binghamton, NY: CSA Publications. . 1999. Cross-National Time Series Archive. Binghamton, NY: Banner Software.

Beck, Nathaniel and Jonathan N. Katz. 1995. What to Do (and Not to Do) with Time-Series Cross-Section Data. American Political Science Review 89:634-647.

Bollen, Kenneth A. 1980. Issues in the Comparative Measurement of Political Democracy. American Sociological Review 45:370-390.

1993. Liberal Democracy: Validity and Methods Factors in Cross-national Measures. American Journal of Political Science 37:1207-1230.

Collier, David and Steven Levitsky. 1997. Democracy with Adjectives: Conceptual Innovation in Comparative Politics. World Politics 49:430-451.

Coppedge, Michael and Wolfgang H. Reinicke. 1991. Measuring Polyarchy. In Alex Inkeles, ed., On Measuring Democracy. New Brunswick: Transaction Publishers.

Dahl, Robert A. 1971. Polyarchy: Participation and Opposition. New Haven: Yale University Press.

Diamond, Larry. 1999. Developing Democracy. Baltimore: Johns Hopkins University Press.

Freedom House. 2001. Freedom House Country Ratings. (http://www.freedomhouse.org/ratings/index.htm)

Gasiorowski, Mark J. 1995. Economic Crisis and Political Regime Change: An Event History Analysis. American Political Science Review 89: 882-897.

Gasiorowski, Mark J. 1996. An Overview of the Political Regime Change Dataset. Comparative Political Studies 29:469-483.

Gasiorowski, Mark J. and Timothy J. Power. 1998. The Structural Determinants of Democratic Consolidation: Evidence from the Third World. Comparative Political Studies 31:740-771.

Gastil, Raymond Duncan. 1991. The Comparative Survey of Freedom: Experiences and Suggestions. In Alex Inkeles, ed., On Measuring Democracy. New Brunswick, NJ: Transaction Publishers.

Gates, Scott, Havard Hegre, Mark P. Jones, and Havard Strand. 2001. Institutional Inconsistency and Political Instability: Polity Duration, 1800-1998. Paper presented at the annual meeting of the International Studies Association, Chicago, February 20-24.

Geddes, Barbara. 1998. What Do We Know about Democratization after Twenty Years? Paper presented at the American Political Science Association meeting, September 3-6, 1998, Boston, MA.

Gleditsch, Kristian S. and Michael D. Ward. 1997. Double Take: a Reexamination of Democracy and Autocracy in Modern Polities. Journal of Conflict Resolution 41:361-383.

Helliwell, John F. 1994. Empirical Linkages between Democracy and Economic Growth. British Journal of Political Science 24:225-248.

Heston, Alan, Robert Summers, Daniel Nuxoll, and Bettina Aten. 1995. Penn World Tables 5.6. http://www.epas.utoronto.ca:5680/pwt/pwt56.html.

Huber, Evelyne, Dietrich Rueschemeyer, and John D. Stephens. 1997. The Paradoxes of Contemporary Democracy: Formal, Participatory, and Social Democracy. Comparative Politics 29:323-342.

Huntington, Samuel P. 1991. The Third Wave. Norman, OK: University of Oklahoma Press.

International Monetary Fund. 1992. International Financial Statistics (CD-ROM). Washington D.C.: International Monetary Fund.

Jaggers, Keith and Ted Robert Gurr. 1995. Tracking Democracy's Third Wave with the Polity III Data. Journal of Peace Research 32:469-482.

Linz, Juan J. 1994. Presidential or Parliamentary Democracy: Does It Make A Difference? In Juan J. Linz and Arturo Valenzuela, eds., The Failure of Presidential Democracy: Comparative Perspectives. Baltimore: Johns Hopkins University Press.

Lipset, Seymour Martin. 1959. Some Social Requisites of Democracy: Economic Development and Political Legitimacy. American Political Science Review 53:69-105.

Mainwaring, Scott and Matthew S. Shugart. 1997. Juan Linz, Presidentialism, and Democracy: A Critical Approach. Comparative Politics 29:449-471.

Mainwaring, Scott, Daniel Brinks, and Anibal Perez-Linan. 2001. Classifying Political Regimes in Latin America, 1945-1999. Studies in Comparative and International Development 36:37-65.

Mallory, Walter, ed. 1950-1962. Political Handbook of the World. New York: Harper and Brothers. ed. 1963-1970. Political Handbook and Atlas of the World. New York: Simon and Schuster. 
Marshall, Monty G. and Keith Jaggers. 2000. Polity IV Dataset and Users' Manual: Political Regime Characteristics and Transitions, 1800-1999. (http://www.bsos.umd.edu/cidcm/polity)

Munck, Gerardo and Jay Verkuilen. Forthcoming. Conceptualizing and Measuring Democracy: Evaluating Alternative Indices. Comparative Political Studies.

Przeworski, Adam. 1991. Democracy and the Market. Cambridge: Cambridge University Press. 2000. Democracy and Development: Political Institutions and Well-being in the World, 19501990. New York: Cambridge University Press.

Rae, Douglas. 1968. A Note on the Fractionalization of Some European Party Systems. Comparative Political Studies 1:413-418.

Sartori, Giovanni. 1997. Comparative Constitutional Engineering, $2^{\text {nd }}$ ed. New York: New York University Press.

Schmitter, Philippe C. and Terry Lynn Karl. 1991. What Democracy Is... and Is Not. Journal of Democracy 2:75-88.

Shugart, Matthew Soberg and John M. Carey. 1992. Presidents and Assemblies. Cambridge: Cambridge University Press.

Stebbins, Richard P. and Alba Amoia, eds. 1970. Political Handbook and Atlas of the World. New York: Simon and Schuster.

1971-1973. The World This Year Supplement to the Political Handbook and Atlas of the World. New York: Simon and Schuster.

United Nations. 1994. The Sex and Age Distribution of the World Populations. New York: United Nations Publications.

Vanhanen, Tatu. 2000a. A New Dataset for Measuring Democracy, 1810-1998. Journal of Peace Research $37: 251-265$.

2000b. The Polyarchy Dataset: Vanhanen's Index of Democracy. (http://www.svt.ntnu.no/iss/data/vanhanen)

World Bank. 1997. World Development Indicators (CD-ROM). Washington D.C.: World Bank. 